Journal author rights and self-archiving: the case of Spanish journals

Melero, R., Rodriguez-Gairín, J.M., Abad-García, F. and Abadal, E.

Post-print of the article published in Learned Publishing, 27: 107-120 doi:10.1087/20140205 


\section{Journal author rights and self-archiving: the case of Spanish}

\section{journals}

Melero, R..$^{1{ }^{*}}$, Rodriguez-Gairín, J.M. ${ }^{2}$, Abad-García, F. ${ }^{3}$ and Abadal, E. ${ }^{2}$

${ }^{1}$ Instituto de Agroquímica y Tecnología de Alimentos-CSIC. Avda Profesor

Escardino 7, 46980 Paterna, Valencia, Spain.

Tel: +34 963900 022; fax: +34 963636 301. E-mail: rmelero@iata.csic.es

${ }^{2}$ Universitat de Barcelona, Facultat de Biblioteconomia i Documentació. Melcior de Palau, 140, 08014 Barcelona, Spain.

Tel: +34 934035 773; fax: +34 934035 772. E-mails: abadal@ub.edu;

rodriguez.gairin@ub.edu

${ }^{3}$ Universidad de Valencia, Facultad de Medicina y Odontología, Departamento

de Historia de la Ciencia y Documentación, Avda. Blasco Ibáñez 15, 46010

Valencia, Spain.

Tel: +34 963864 164; fax: +34 963613 975. E-mail: abad@uv.es

\section{Abstract}

Open-access literature is digital, online, free of charge, and free of most copyright and licensing restriction. The lack of clarity of publisher permissions for archiving in open access repositories affects the adoption of the green OA route. The paper explores editorial policies and self-archiving conditions in 1615 Spanish scholarly journals. $48 \%$ are published by university and research institutions, $25 \%$ by associations/societies, and $17 \%$ by commercial publishers; Social Sciences and Humanities (SSH) accounted for $67 \%$ of the journals (44.5\% and $22.5 \%$, respectively) followed by health sciences $(20 \%)$; $71 \%$ offered gratis access immediately after publication, and $11 \%$ after an embargo; $31 \%$ provided any mention about author rights. Self-archiving was specifically allowed by $65 \%$ of the journals; $52 \%$ were classified as ROMEOblue, $12 \%$ as green and $15 \%$ as white, and $21 \%$ could not be classified; $21 \%$ used some type of CC licenses, mostly in SSH. 


\section{INTRODUCTION}

The Budapest Open Access Initiative (BOAl, 2002) ${ }^{1}$ defines open access thus:

By "open access" to this literature, we mean its free availability on the public internet, permitting any users to read, download, copy, distribute, print, search, or link to the full texts of these articles, crawl them for indexing, pass them as data to software, or use them for any other lawful purpose, without financial, legal, or technical barriers other than those inseparable from gaining access to the internet itself. The only constraint on reproduction and distribution, and the only role for copyright in this domain, should be to give authors control over the integrity of their work and the right to be properly acknowledged and cited.

As the BOAI indicates, having open access to scientific and scholarly outputs is closely tied to the issue of permissions required of both humans and machines to reuse scholarly works; not only to download and read them, but also to be integrated into other, interoperable information ecosystems comprising larger information resources (Andrew et al., 2011). Beyond fair use, the use of papers published in scholarly journals is subject to the permissions granted by the copyright holders, for example, for archiving in open access repositories, for commercial use or for any other purposes. Therefore, it is essential for journals to define their editorial policies on exploitation rights and economic rights, whether or not these are restrictive.

According to Spanish intellectual property law (Government of Spain, 2006, harmonized with European Directive 2001/29/EC), author rights include moral and economic rights. Moral rights are not transferable and include the attribution of authorship and the integrity of the work; economic rights include copyright (right to make copies and derivative works, distribution, display and performance). Economic rights are transferable in whole or in part, and have spatial and temporal coverage. In the case of scholarly publishing, when the copyright assignment is not exclusive, authors and publishers have to negotiate the terms upon which either party uses the work; when copyright is exclusively transferred, the publisher is the sole owner and decides how authors and readers can use the papers. This does not mean that the publisher 
can impose restrictions per se. In fact there are some journals that distribute their papers under publication licenses that allow their reuse under certain conditions, such as Creative Commons (CC) licenses ${ }^{2}$. In brief, a journal's copyright policy identifies and defines the copyright owner and author and publisher rights, respectively.

A license for publication can also be created following a model, like the SURF Foundation license ${ }^{4}$ (2006), which specifies the rights reserved by authors and publishers for optimal access, including the rights for educational or research use, and for dissemination. Authors and/or publishers can create their own license, but every case should answer some basic questions. First, which versions of the work are reusable? (The author pre-print, the author post-print or the version of record?). Second, when are versions reusable? (Immediately after acceptance or after publication? After an embargo?) Third, what purposes do versions serve? (Academic and research purposes? Commercial purposes?) And fourth, is the creation of derivative works allowed? (And if it is, should share-alike involve the derivative work?). These questions can help authors or publishers create a license to publish with the basic provisions to reuse the work without permission of the copyright holder. In this sense, the SURF-hosted Copyright Toolbox ${ }^{5}$ provides sample wording to define these provisions about the further use of works and their meaning.

Since 2006 the open access movement in Spain has steadily gained momentum resulting in an increase of institutional open access repositories, the adoption of new open access policies, launch of new OA journals and conversion of older ones to OA, among other OA initiatives (Abadal et al., 2011). Some of those journals have also adopted an increasing number of open licenses. However, the terminology used in editorial policies to describe rights issues is still inadequate, as indicated in previous studies on information science journals (Coleman, 2007) and on several social sciences disciplines (Antelman, 2006). This lack of clarity in publishers policies leaves authors concerned that they might infringe copyright, and that inhibits depositing in open access repositories (Fry et al, 2009). In addition, policies can change over time, and this means that librarians and repositories managers have to contact publishers to ask permission to deposit material (Ramirez and Hanlon, 2011). Tools like SHERPA/ROMEO can assist copyright clearance. However up to 2011 very few Spanish journals were recorded in the SHERPA/RoMEO ${ }^{6}$ 
database of publisher policies on copyrights and permissions for self-archiving. This was one reason why the Spanish research group Acceso Abierto a la Ciencia ${ }^{7}$ ("Open Access to Science") started to map Spanish scholarly journals in terms of author rights and permissions for self-archiving works in institutional and subject repositories and on personal web pages. This information has been collected in a database attached to the portal DULCINEA $^{8}$, which also classifies journals using SHERPA/RoMEO color taxonomy. While RoMEO was the inspiration for the directory, DULCINEA has provided the groundwork for a number of other directories: the directory of French scholarly journals Héloïse ${ }^{9}$ (Dillaerts and Chartron, 2013), the Brazilian portal Diadorim ${ }^{10}$, and the Portuguese project Blimunda ${ }^{11}$ (all of which also share RoMEO taxonomy).

Preliminary results (Melero et al., 2009; Melero et al, 2011) provided very useful information to go on with a further systematic study regarding copyright terms in the case of Spanish scholarly journals. This study sought to analyse editorial policies on copyright and permissions for self-archiving in open access repositories by discipline, publisher, use of open licenses, permissions, version allowed to deposit and online access.

\section{METHODOLOGY}

The study examined the Spanish scholarly journals that are active and visible in the Internet, at least to the level of list of contents. Spanish refers to journals created in Spain, regardless of publisher origin (Elsevier, Springer, etc.), scholarly refers to journals that published any smaller or larger number of peer-reviewed original research articles per volume, and active refers to journals that were being published at the time of the study (note that whenever a delay in publication was detected, the editors were contacted to confirm that their journal was still active); finally, visible means either that the journal's contents were available online (regardless of the type of access required) or at least the journal had a webpage with list of contents, contact persons and general information about the journal.

The first list of journals titles was compiled using the CSIC databases ${ }^{13}$, Dialnet ${ }^{14}$, the directory and catalog Latindex ${ }^{15}$ and the directory Ulrichsweb ${ }^{16}$. After title lists were compared and duplicates had been removed, the list of 
2411 journals was further reduced to 1628 after a thorough check on journal adequacy and status (see the criteria above) because part of them ( $n=783$ ) were inactive, or did not correspond to a serial title or they were not peerreviewed. New titles have since been added and the number of journals varied according to the source (the CSIC databases and the repository Dialnet each list approximately 1900 titles, Latindex lists approximately 1700 and Ulrichsweb provides over 2000); overall, however, we estimate the number of Spanish scholarly journals active and visible on the Internet might between 1700 and 1800 . The sample used in the study comprised 1615 titles. The study covers journals analyzed until September 2013, which according to this estimate represents approximately $90 \%$ of existing active Spanish journals. Data collection was conducted using an online survey sent to journal editors and was then continued using a manual search on the Internet and direct enquiries to editors and publishers by email or telephone.

\section{The DULCINEA database}

Journal data were collected in a database, browsable through the DULCINEA portal and comprising the following metadata:

- Identification details and contact person. The identification details included title, ISSN, e-ISSN, type of publisher, URL, and discipline, while contact issues included the person's name, email address and phone. Seven publisher types were considered: university and research institutions; commercial and private publishers; professional and learned associations and societies; museums; foundations; royal academies; and governmental bodies. Eight disciplines were considered: Social Sciences; Humanities; Health Sciences; Life Sciences; Fine and Performing Arts; Engineering; Experimental Sciences; and Mathematics and Physical Sciences.

- Type of online access. The types considered were: restricted to subscribers; gratis; and gratis after an embargo period expressed in months.

- Information regarding mention or description of rights, type of CC license used [if any], permission for self-archiving and version allowed to deposit. 
The versions considered were: the author pre-print, the author post-print and the version of record.

Finally, journals were classified according to RoMEO colors (Jenkings et al., 2007) depending on the permissions for self-archiving in an institutional or subject repository or in personal web pages, where 'green' means that both the pre-print and post-print could be archived, 'blue' indicates that the postprint could be archived, 'yellow' means that the pre-print could be archived, and white indicates that archiving was not formally supported.

\section{Statistical Analysis}

A multiple correspondence analysis was performed to detect underlying relationships or associations within journals using the following variables and their modalities: discipline, publisher, rights statement, online access, permission for self-archiving, RoMEO color, and use of CC licenses.

\section{RESULTS AND DISCUSSION}

\section{Journal profile}

\section{Discipline and publisher}

As Table 1 shows, journals publishing in the two disciplines Social Sciences and Humanities together accounted for $67 \%$ of the journals $(44.5 \%$ and $22.5 \%$, respectively), followed by Health Sciences, which accounted for $20 \%$. Social sciences and humanities journals were published mostly by universities and research institutions (63\%) while health sciences journals were mainly produced and distributed by private and commercial publishers (47\%) followed by professional associations and societies (35\%).

\section{Insert Table 1 here}

The fact that most journals in health sciences were published by commercial companies can be attributed in part to Elsevier's acquisition in 2005 of Doyma, the former leading Spanish publisher of medical journals. Elsevier has since then added new titles besides Doyma's portfolio so that it now covers nearly 
half of all Spanish journals in this discipline, most of which were already high ranked in Thomson Reuters ISI Journal Citation Reports. The main reason for the predominance of journals in Social Sciences and Humanities is that faculty and researchers in those disciplines usually publish in their own language, therefore Spanish journals are a good venue to submit their works, especially to those which have already a recognised international prestige. Furthermore, and in contrast to the medical, experimental and life sciences (where distribution channels are through the well-known journals), SSHH researchers have difficulties in finding a place for their publications because of the difference in number of indexed journals used for research evaluation exercises frames. Also in recent years a relatively large number of social sciences and humanities journals have been included in both Scopus and ISI databases. Data for 2011 indicated that Spanish publications indexed by Thomson Reuters-ISI had experienced a growth rate of 6\%, putting Spain in the tenth position in a list of countries that included Brazil, the UK, Japan and Sweden (Fecyt 2011): in 2008, only 16 (30\%) of the total of 53 Spanish journals were social science publications, while in 2011 they were 54 (41\%) of a total of 132.

\section{Publisher and online access}

Table 2 shows the type of journal online access (gratis, gratis after an embargo or restricted to subscribers) granted by different type of publisher types: In the sample, $71 \%$ of all the journals were available free of economic barriers (gratis) and if we add those journals which are gratis after an embargo, this results in $82 \%$, mostly published by universities and/or and research institutions.

\section{Insert table 2 here}

Embargo periods were generally between three to twelve months, as occurs in other journals (HighWire Press ${ }^{17}$ ), but could occasionally be of 24,36 or 48 months. The online content of journals published by commercial publishers was generally restricted to subscribers, although some journals published by Elsevier but owned by a professional association or learned society offered unrestricted online access (see Table 3). A number of Spanish journals published by Elsevier are also distributed through the portal SciELO Spain with 
an embargo on most recent issues. These included Clínica y Salud, Gaceta Sanitaria, Revista Andaluza de Medicina del Deporte, Revista de Psicologia del Trabajo y de las Organizaciones and Revista Española de Cirugía Oral y Maxilofacial.

\section{Insert table 3 here}

Author rights and permissions for self-archiving

The specification of copyright terms and permissions for self-archiving has not been widely practised in scholarly publishing, as Gadd et al. (2003) and Coleman (2007) detected during the analysis of scholarly publisher's copyright agreements. In fact, a high percentage of the journals in our study (31\%) did not mention any of the terms commonly used to describe copyright. At the same time, however, when journal editors or publishers were directly consulted about author rights and permissions for self-archiving materials, their responses were in general, positive and permissions were granted (see Table 4).

\section{Insert table 4 here}

Direct contact with editors also contributed to widespread good practices on how to choose publication licenses and define author rights (Melero, 2010).

For the location of the copyright or exploitation rights description, we used home web pages, instructions to authors and files accessed through hyperlinks. Commercial and private were the types of publisher best to define authors rights, followed by universities and research institutions (Figure 1).

\section{Insert figure 1 here}

Social Sciences and Health Sciences were the two disciplines in which copyright terms were most clearly located and defined (Figure 2).

Insert figure $\mathbf{2}$ here

Because of its specific tabs for copyright notice and open access policies, the open-source software Open Journal Systems (OJS) has contributed to defining and locating copyright policies more easily. In our sample, 210 journals used OJS, and of those, 53\% were social science journals and $21 \%$ were humanities journals, thus providing figures that were slightly higher than 
those obtained previously by a survey among journals created with OJS (Edgar and Willinsky, 2010). In Spain, the universities Universitat de Barcelona, Universidad Carlos III de Madrid, Universidad Complutense de Madrid, Universidad de Granada, Universidad de Murcia, Universitat Oberta de Catalunya, Universidad Pablo de Olavide, and Universitat Politècnica de València have all adopted OJS software to create and manage their scholarly journals. Note that OJS offers the advantage that it is OAI-PMH compliant ${ }^{18}$ and can be harvested by an OAI-PMH service provider. It also complies with the SWORD protocol, which allows file transfers from the journal to an open access repository created with DSpace or Fedora.

The study also considered the type of access regarding specification of copyright issues (see Figure 3). Among the journals whose contents were restricted to subscribers ( $N=285), 62 \%$ presented no description of copyright, and many were published by Elsevier ${ }^{19}$ and Springer ${ }^{20}$, whose policies are the same for journals from other countries. In journals with free (gratis) access and with free access after an embargo, the mention or description of author rights terms appeared in $72 \%$ and $57 \%$ of the cases, respectively.

\section{Insert figure 3 here}

\section{Permissions for self-archiving}

Sixty four percent of the journals allowed self-archiving, 15\% did not allow self-archiving or deposit, and for the remaining $21 \%$ no information was available. The publishers that contributed most to the number of journals allowing self-archiving were universities and research institutions and other public bodies such as museums (see Figure 4).

\section{Insert Figure 4here}

Within disciplines, the most striking differences were between the category Health Sciences and the category Mathematics and Physics (see Figure 5), the former published mainly by commercial and private companies and the latter group apparently affected by the habit of researchers for selfarchiving in the subject repository Arxiv.

\section{Insert Figure 5 here}

If we compare data about online access type and permission for selfarchiving, 43\% of the journals met the conditions of gratis and "libre" (Suber, 2008) and, regardless of the access type they offered, $64 \%$ of the journals permitted self-archiving. Regarding the statement of rights and permissions, 
some journal editors declared that they allowed self-archiving when they were directly consulted, even though their journal policy statement made no reference to this (see Table 4).

\section{Classification of journals according to RoMEO colors}

Depending on which version could be deposited in institutional or subject repositories and on personal web pages, journals were classified using SHERPA / RoMEO colors. As Figure 6 shows, 64\% allowed self-archiving of some version of work (the author pre-print, the author post-print or version of record). These data are similar to the data provided by RoMEO about the journals contained in its database (Millington et al, 2011).

\section{Insert figure 6 here}

Note that in the case of blue journals with free access, the most frequently chosen version was the version of record (see Figure 7).

\section{Insert figure 7 here}

In the case of toll access journals published by commercial and private companies the predominant color was green (Figure 8), a reflection of the large number of journals published by Elsevier and its editorial policy for selfarchiving, although this condition is also subject to the existence of institutional OA mandates.

\section{Insert Figure 8 here}

Social Sciences and Humanities journals together represented $73 \%$ of the total blue journals (see Figure 9).

\section{Insert figure 9 here}

As Table 5 shows, a total of 332 journals (21\% of the journals examined) distributed their contents under CC licenses. This is 3 percent higher than that found in an earlier study (Abad-García et al., 2013) in support of the view that this is an increasing trend since they were created (Linksvayer, 2011). Again, social science and humanities journals used proportionally more CC licenses than other disciplines, and universities and research institutions were the publishers generating the largest number of journals with these licenses.

\section{Insert Table 5 here}

Statistical analysis of qualitative variables 
Multiple correspondence analysis of the variables discipline, publisher, access, rights statement, permissions, use of CC licenses and RoMEO color is described by the graph in Figure 10. One strong association was found among the journals published by universities and research institutions, Social Sciences, Humanities and Engineering, free access, blue ROMEO color coding, and permission for self-archiving. At the opposite extreme are the health science journals with restricted access published by commercial and private publishers. In the center of the graph we see the journals published by foundations, scientific associations and societies, and governmental bodies, mainly in the disciplines life sciences, experimental sciences, and physics.

\section{Insert figure 10 here}

According to these results, a high percentage of Spanish scholarly journals appear to share the following features:

- they are published by a university or research institution;

- they are dedicated to the study of the social sciences or the humanities;

- online access is free (gratis);

- copyright and author rights are visibly described;

- they allow self-archiving of the author post-print or the version of record;

- RoMEO color classifies them as blue journals.

\section{CONCLUSIONS}

As we have seen, social sciences and humanties journals dominate, and this affects the analyses. There are several reasons for this. One is the Spanish social scientist's tendency to publish in his or her own language, even though many Spanish journals also accept papers in English or in other languages, like French or Portuguese. Another reason is that certain Spanish-language social science and humanities journals were launched more than 50 years ago (e.g., Archivo Español de Arte in 1925, Hispania and Revista de Educación in 1940, Anuario Musical in 1946 or Anales Cervantinos in 1951) and have been consolidated and recognized by readers and authors to the degree that they also have international prestige. A third reason is that most of these journals are published by universities and research institutions, whose policies 
favouring open access to scholarly outputs we believe have contributed to the good health and sustainability of the journals they publish.

Turning to the second-most common group of Spanish scholarly journals, the journals dedicated to the The second biggest group, health sciences, have two distinct sub-sets : those from commercial and private publishers like Elsevier, Springer, Aran Ediciones or Viguera Editores that restrict access by subscription fees (although some publishers allow selfarchiving of the author pre-print or post-print); and journals published by those from professional and associations and learned societies, universities and research institutions that offer free (gratis) access and allow self-archiving in open access repositories. Clearly the acquisition of a large Spanish publisher by Elsevier has had a substantial affect on the scene

Self-archiving is allowed for at least $65 \%$ of journals. This implies a high level of compliance with OA policies at national, European and international levels for mandating to deposit

We found that there is often still a lack of clarity, indeed complete absence in some cases, in stated policies on author rights and archiving. Publishers could help the rest of the community by rectifying this. 


\section{Acknowledgements}

This research was funded by the Spanish Plan Nacional de I+D, project "Open access to science in Spain: the degree of implementation and sustainability of a new model of scholarly communication" ( refs. CSO2011-29503-C02-02 and CSO2011-29503-C02-02).

\section{Footnotes}

1. Budapest Open Access Initiative. Available at http://www.soros.org/openacces

2. Creative Commons España. Available at http://es.creativecommons.org

3. Open Knowledge Definition. Available at http://opendefinition.org/okd

4. SURF Foundation license. Available at http://copyrighttoolbox.surf.nl/copyrighttoolbox/publishers/licence

5. SURF Foundation: Copyright toolbox. Available at http://copyrighttoolbox.surf.nl/copyrighttoolbox/authors/sample-wording/futurereuse/provisions

6. SHERPA/RoMEO: Publisher copyright policies \& self-archiving. Available at http://www.sherpa.ac.uk/romeo

7. Grupo de investigación "Acceso abierto a la ciencia". Available at http://www.accesoabierto.net

8. Dulcinea: Derechos de copyright y las condiciones de auto-archivo de revistas científicas españolas. Available at http://www.accesoabierto.net/dulcinea 9. Héloïse: Politiques des éditeurs en matière de dépôt des articles. Available at http://heloise.ccsd.cnrs.fr/?lang=en

10. Diadorim: Diretório de políticas de acesso aberto das revistas científicas brasileiras. Available at http://diadorim.ibict.br

11. Repositório Científico de Acesso Aberto de Portugal (RCAAP): Blimunda.

Available at http://projecto.rcaap.pt/index.php/lang-pt/sobre-orcaap/servicos/projecto-blimunda

13. Consejo Superior de Investigaciones Científicas (CSIC): Database. Available at http://www.csic.es/web/guest/bases-de-datos

14. Dialnet. Available at http://dialnet.unirioja.es

15. Latindex. Available at http://www.latindex.unam.mx 
16. Ulrich's Periodicals Directory. Available at http://www.ulrichsweb.com 17. HighWire Press: free online full-text articles. Available at http://highwire.stanford.edu/lists/freeart.dtl

18. Public Knowledge Project: SWORD plugin. Available at http://pkp.sfu.ca/node/ 1777

19. Elsevier: Author rights. Available at http://www.elsevier.com/authors/authorrights-and-responsibilities

20. Authors' Rights with Springer. Available at http://www.springer.com/open+access/authors+rights

\section{Literature}

Abad-García,F. M., Melero, R., Rodríguez-Gairín, J.M. and Abadal E. 2013. Author rights vs self-archiving in Spanish scientific journals. Procedia - Social and Behavioral Sciences 73: 764 - 768. http://dx.doi.org/ 10.1016/j.sbspro.2013.02.116

Abadal, E., Anglada, L., Melero, R., Abad, F., Térmens, M. and Rodríguez-Gairín, J.M. (2010). Open access in Spain. In Anglada, L., \& Abadal, E. (eds.), Open access in Southern European countries. Madrid, FECYT, pp-101-115 . Available at http://www.accesoabierto.net/sites/accesoabierto.net/files/OASouthEurope.pdf (accesed 8 January 2014).

Andrew, T., Burnhill P., Fraser, S., Macdonald, S., Osborne, N., Rees C., Rice, R., Rusbridge, A., Stuart I.,Taylor, R. and Waller, G., 2011. Mapping the repository landscape. Poster presented at Repository Fringe, Edinburgh, UK. Available at http://edina.ac.uk/presentations publications/mtrl (accesed 8 January 2014).

Antelman, K. , 2006. Self-archiving practice and the influence of publisher policies in the social sciences. Learned Publishing 19: 85-95.

Budapest Open Access Initiative 2011. Ten years on from the Budapest Open Access Initiative: setting the default to open. Available at http://www.opensocietyfoundations.org/openaccess/boai-10-recommendations (accesed 8 January 2014). 
Coleman,C., 2007. Self-archiving and the Copyright Transfer Agreements of ISIranked library and information science journals. Journal of the American Society for Information Science and Technology 58: 286-296.

Dillaerts, H. and Chartron, G., 2013. Héloïse: towards a co-ordinated ecosystem approach for archiving of scientific publications? Learned Publishing 26: 173-179.

Edgar, B.D. and Willinsky, J. (2010). A survey of the scholarly journals using Open Journal Systems. Scholarly and Research Communication 1: 020105. Available at http://src-online.ca/index.php/src/article/view/24 (accesed 8 January 2014).

European Commission. Directive 2001/29/EC of the European Parliament and of the Council of 22 May 2001 on the harmonisation of certain aspects of copyright and related rights in the information society, 2001. Available at http://eurlex.europa.eu/LexUriServ/LexUriServ.do?uri=OJ:L:2001:167:0010:0019:EN:PDF (accesed 8 January 2014).

Fecyt. Análisis de la presencia de las revistas científicas Españolas en el JCR de 2011, Fecyt 2011. Available at http://www.accesowok.fecyt.es/wpcontent/uploads/2012/07/2012 07 10RevEspanolasJCR2011 Vdef.pdf (accesed 8 January 2014).

Fry, J., Oppenheim ,C., Probets, S., Creaser, C., Greenwood, H., Spezi, V. and White, S. PEER behavioural research: Authors and users vis-à-vis journals and repositories.

Baseline report, 200. Available at http://www.peerproject.eu/ fileadmin/media/reports/Final_revision_-_behavioural_baseline_report__20_01_10.

pdf.

Gadd, E., Oppenheim, C. and Probets, S. (2003). RoMEO Studies 4: An analysis of journal publishers' copyright agreements. Learned Publishing: 16: 293-308. http://www.accesoabierto.net/es/biblio/export/tagged/73 
Gobierno de España. Ley de propiedad intelectual-derechos de autor. Boletín Oficial del Estado, July 8, 2006. Available at http://www.boe.es/boe/dias/2006/07/08/pdfs/A25561-25572.pdf (accesed 8 January 2014).

Jenkins C., Probets S., Oppenheim C. and Hubbard B. 2007. RoMEO Studies 8: Selfarchiving: the logic behind the colour-coding used in the Copyright Knowledge Bank. Electronic Library and Information Systems 41: 124-133

Linksvayer, M. 2011. The power of open: over 400 million CC-licensed works, with increasing freedom. Available at http://creativecommons.org/weblog/entry/28041 (accesed 8 January 2014).

Melero, R. 2010. Guía práctica sobre los derechos patrimoniales o de explotación (copyright) y su relación con el auto-archivo en repositorios de acceso abierto. Available at http://www.accesoabierto.net/sites/accesoabierto.net/files/melero guiaderechos2.pdf (accesed 8 January 2014).

Melero, R., Abad-García, M.F., Abadal, E., and Rodríguez-Gairín, J.M. DULCINEA: Copyright policies and type of access to Spanish scientific journals. Presentation at ELPUB 2009: 13th International Conference on Electronic Publishing. Rethinking Electronic Publishing: Innovation in Communication Paradigms and Technologies. Milan, Italy 10-12 June 2009. Available at Ihttp://digital.csic.es/handle/10261/27906 (accesed 8 January 2014).

Melero, R., Rodríguez-Gairín, J.M., Abad-García, M.F., and Abadal, E. 2011. What is the colour of your journal? Case based on Spanish scientific journals. Presentation at PKP Scholarly Publishing Conference 2011, Berlin, Germany. Available at http://pkp.sfu.ca/ocs/pkp/index.php/pkp2011/pkp2011/paper/view/300

Millington, P., Smith, J.H., Hussain, A., \& Hubbard, B. 2011. SHERPA/RoMEO Journals. Prsentation at Open Repositories 2011, Austin, Texas USA. Available at 
https://conferences.tdl.org/or/OR2011/OR2011main/paper/view/380/88 (accesed 8 January 2014).

Suber, P. 2008. Green/gold OA and gratis/libre OA. Available at http://www.earlham.edu/ peters/fos/2008/08/greengold-oa-and-gratislibreoa.html

Ramirez, M. and Hanlon, A. (2011). Asking for permission: A survey of copyright workflows for institutional repositories, portal: Libraries and the Academy 11: 683702. Available at http://works.bepress.com/marisa ramirez/18/ (accesed 8 January 2014). 


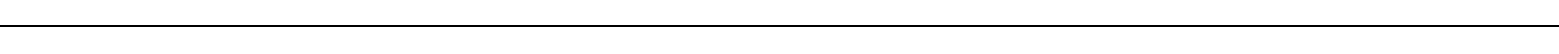


Table 1. Frequency of journals classified by type of publisher and discipline (values in brackets indicate corresponding percentages by rows)

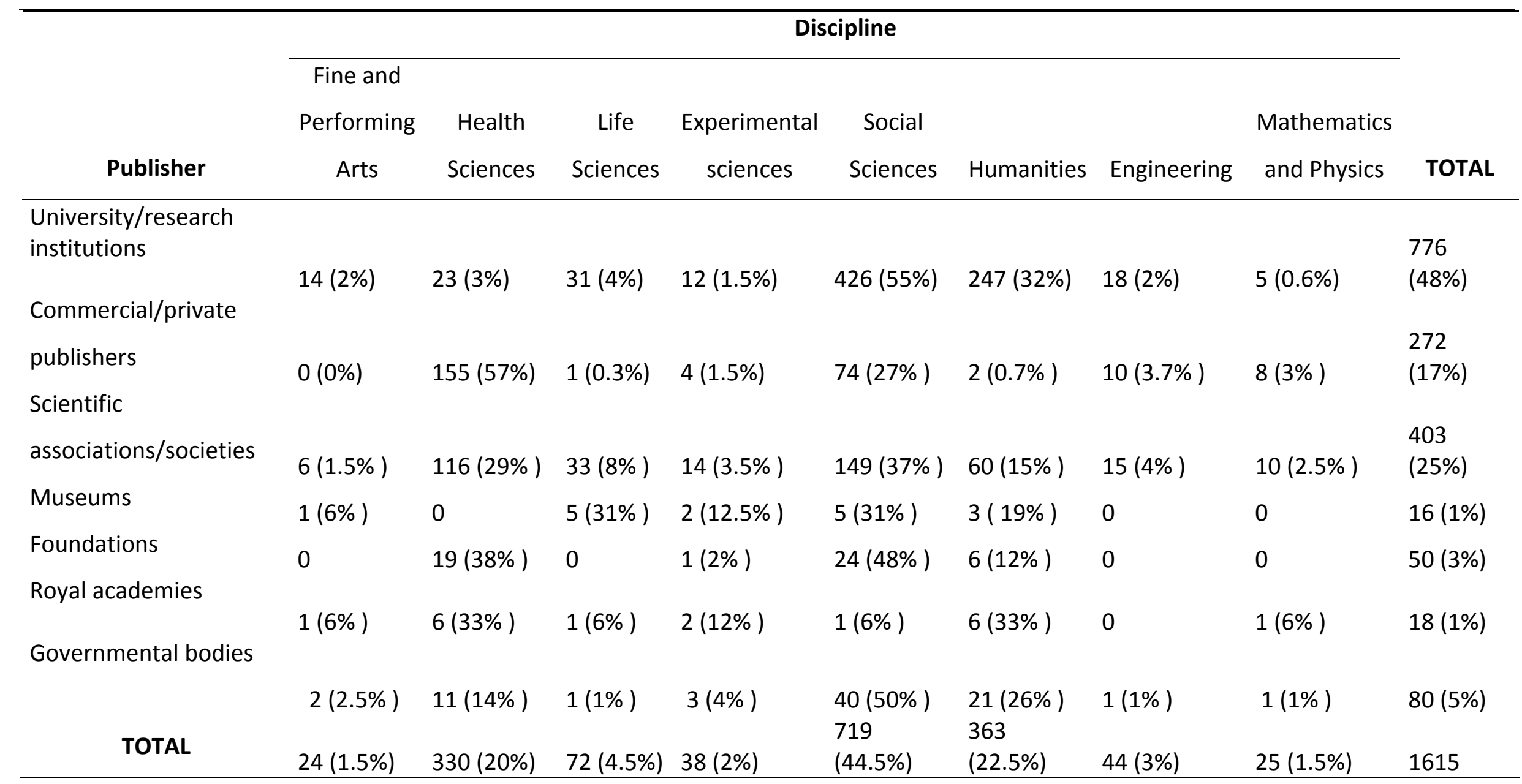


Table 2. Frequency of journals by type of publisher and online access (values in brackets indicate corresponding percentages by rows)

\begin{tabular}{|c|c|c|c|c|}
\hline \multirow[b]{3}{*}{ Publisher } & \multicolumn{4}{|c|}{ Online access } \\
\hline & \multirow[b]{2}{*}{ Gratis } & \multicolumn{3}{|c|}{ Restricted } \\
\hline & & $\begin{array}{c}\text { Gratis after an } \\
\text { embargo }\end{array}$ & $\begin{array}{c}\text { to } \\
\text { subscribers }\end{array}$ & TOTAL \\
\hline \multirow[t]{2}{*}{$\begin{array}{l}\text { University/research } \\
\text { institutions }\end{array}$} & 617 & & & \\
\hline & $(79.5 \%)$ & $113(14.5 \%)$ & $46(6 \%)$ & 776 \\
\hline \multicolumn{5}{|l|}{ Commercial/private } \\
\hline publishers & $110(40 \%)$ & $16(6 \%)$ & $146(54 \%)$ & 272 \\
\hline \multicolumn{5}{|l|}{ Scientific } \\
\hline associations/societies & $305(76 \%)$ & $35(9 \%)$ & $63(16 \%)$ & 403 \\
\hline Museums & $12(75 \%)$ & $2(12.5 \%)$ & $2(12.5 \%)$ & 16 \\
\hline Foundations & 27 (54\%) & $3(6 \%)$ & $20(40 \%)$ & 50 \\
\hline \multicolumn{5}{|l|}{ Royal academies } \\
\hline & $14(77 \%)$ & $1(6 \%)$ & $3(16 \%)$ & 18 \\
\hline & $64(80 \%)$ & $11(12.5)$ & $5(7.5 \%)$ & 80 \\
\hline & 1149 & & & \\
\hline TOTAL & $(71 \%)$ & $181(11 \%)$ & $285(18 \%)$ & 1615 \\
\hline
\end{tabular}


Table 3. Spanish biomedical journals published by Elsevier with free online access and subscription for print versions

\begin{tabular}{|c|c|}
\hline Journal & Owner of the journal \\
\hline Anales de Pediatría & Asociación Española de Pediatría \\
\hline \multirow[t]{2}{*}{ Apunts Medicina de l'Esport } & Consell Català de l'Esport \\
\hline & Sociedad Española de Medicina de Familia y \\
\hline Atención Primaria & Comunitaria \\
\hline \multirow[t]{2}{*}{ Cardiocore } & Sociedad Andaluza de Cardiología \\
\hline & Sociedad Española de Cirugía Torácica y \\
\hline \multirow[t]{2}{*}{ Cirugía Cardioovasular } & Cardiovascular \\
\hline & Sociedad Española de Arteriosclerosis, \\
\hline Clínica e Investigación en & Sociedad Latinoamericana de Aterosclerosis, \\
\hline \multicolumn{2}{|l|}{ Investigaciones Europeas de } \\
\hline Dirección y Economía de la & Academia Europea de Dirección y Economía de la \\
\hline Empresa & Empresa \\
\hline Enfermedades Infecciosas y & Sociedad Española de Enfermedades Infecciosas \\
\hline Microbiología Clínica & y Microbiología Clínica \\
\hline Clinica y Salud & $\begin{array}{l}\text { Colegio Oficial de Psicólogos de Madrid } \\
\text { Sociedad Española de Salud Pública y }\end{array}$ \\
\hline Gaceta Sanitaria & Administración Sanitaria \\
\hline Intervención Psicosocial & Colegio Oficial de Psicólogos de Madrid \\
\hline Psicología Educativa & Colegio Oficial de Psicólogos de Madrid \\
\hline \multicolumn{2}{|l|}{ Revista de Psicología del Trabajo y } \\
\hline de las Organizaciones & Colegio Oficial de Psicólogos de Madrid \\
\hline Neurología & Sociedad Española de Neurología \\
\hline \multicolumn{2}{|l|}{ Seminarios de la Fundación } \\
\hline \multirow[t]{2}{*}{ Española de Reumatología } & Sociedad Española de Reumatología \\
\hline & Sociedad Española de Reumatología, Colegio \\
\hline Reumatología Clínica & Mexicano de Reumatología \\
\hline \multicolumn{2}{|l|}{ Revista Andaluza de Medicina del } \\
\hline Deporte & Centro Andaluz de Medicina del Deporte \\
\hline \multicolumn{2}{|l|}{$\begin{array}{l}\text { Revista Científica de la Sociedad } \\
\text { Española de Enfermería }\end{array}$} \\
\hline Neurológica & Sociedad Española de Enfermería Neurológica \\
\hline Revista de Psiquiatría y Salud & Sociedad Española de Psiquiatría, Sociedad \\
\hline Mental & Española de Psquiatría Biológica \\
\hline \multicolumn{2}{|l|}{ Revista Médica Internacional sobre } \\
\hline el Síndrome de Down & Fundació Catalana Síndrome de Down \\
\hline \multicolumn{2}{|l|}{ RIAI: Revista Iberoamericana de } \\
\hline \multirow[t]{2}{*}{ Automática e Informática Industrial } & Comité Español de Automática \\
\hline & Sociedad Española de Médicos de Atención \\
\hline SEMERGEN & Primaria \\
\hline Trastornos Adictivos & Sociedad Española de Toxicomanías \\
\hline
\end{tabular}


Table 4. Frequency of journals that allow self-archiving by access and rights description (values in brackets indicate corresponding percentages by rows)

\begin{tabular}{llll}
\hline \multirow{2}{*}{ Access and rights } & \multicolumn{3}{c}{ Self-archiving } \\
\cline { 2 - 4 } \multicolumn{1}{c}{ Gratis } & Not allowed & Unknown & Allowed \\
Gratis after an embargo & $127(11 \%)$ & $198(17 \%)$ & $824(72 \%)$ \\
Restricted to subscribers & $28(15 \%)$ & $34(19 \%)$ & $119(66 \%)$ \\
\multicolumn{1}{c}{ Total } & $80(28 \%)$ & $102(36 \%)$ & $103(46 \%)$ \\
& $235(15 \%)$ & $334(21 \%)$ & $1046(64 \%)$ \\
No rights description & & & \\
Rights are described/mentioned & $216(19 \%)$ & $68(6)$ & $825(75 \%)$ \\
\hline
\end{tabular}


Table 5. Number of journals using CC licences

\begin{tabular}{|c|c|c|c|}
\hline & \multicolumn{3}{|c|}{ Use of CC licenses } \\
\hline & $\begin{array}{c}\text { Total } \\
\text { journals }\end{array}$ & $\begin{array}{c}\text { No } \\
\text { journals }\end{array}$ & Percentage \\
\hline \multicolumn{4}{|l|}{ By Discipline } \\
\hline Fine and Performing Arts & 24 & 7 & 29 \\
\hline Health Sciences & 330 & 26 & 8 \\
\hline Life Sciences & 72 & 19 & 26 \\
\hline Experimental Sciences & 38 & 7 & 18 \\
\hline Social Sciences & 719 & 182 & 25 \\
\hline Humanities & 363 & 78 & 21 \\
\hline Engineering & 44 & 9 & 20 \\
\hline $\begin{array}{c}\text { Mathematics and Physics } \\
\text { By Publisher }\end{array}$ & 25 & 4 & 16 \\
\hline $\begin{array}{l}\text { University/research } \\
\text { institutions }\end{array}$ & 776 & 207 & 27 \\
\hline $\begin{array}{l}\text { Commercial/private } \\
\text { publishers }\end{array}$ & 272 & 19 & 7 \\
\hline Scientific & & & \\
\hline associations/societies & 403 & 85 & 21 \\
\hline Museums & 16 & 3 & 19 \\
\hline Foundations & 50 & 6 & 12 \\
\hline Royal academies & 18 & 1 & 6 \\
\hline Governmental bodies & 80 & 11 & 14 \\
\hline
\end{tabular}


Figure 1. Mention of author rights by type of publisher

Figure 2. Mention of author rights by discipline

Figure 3. Mention of author rights by type of access to online journal contents

Figure 4. Permission for self-archiving by type of publisher

Figure 5. Permission for self-archiving by discipline

Figure 6. Spanish scholarly journals by RoMEO color

Figure 7. Journals by type of online access against RoMEO colors

Figure 8. Journals by RoMEO color against subject discipline

Figure 9. Journals by RoMEO color against type of publisher

Figure 10. Two-dimensional representation of the multiple correspondence analysis with the following variables and their modalities: discipline (cat), type of publisher (Edit), rights statement (rights), access (Acc), permission for self-archiving (self-arch), RoMEO color and use of Creative Commons licenses. Cat1: Fine and Performing Arts; Cat2: Health Sciences; Cat3: Life Sciences; Cat4: Experimental Sciences; Cat5: Social Sciences; Cat6 Humanities; Cat7: Engineering; Cat7: Mathematics and Physical Sciences. Edit1: university and research institutions; Edit2: commercial and private publishers; Edit3: scientific associations and societies; Edit4: museums; Edit 5: foundations; Edit 6: royal academies; and Edit (7) governmental bodies. Acc1: Free access; Acc2: gratis after an embargo; Acc3: Access restricted to susbscribers. Self-arch0: Not allowed; self-arch1: not mentioned; Self-arch1: allowed. 


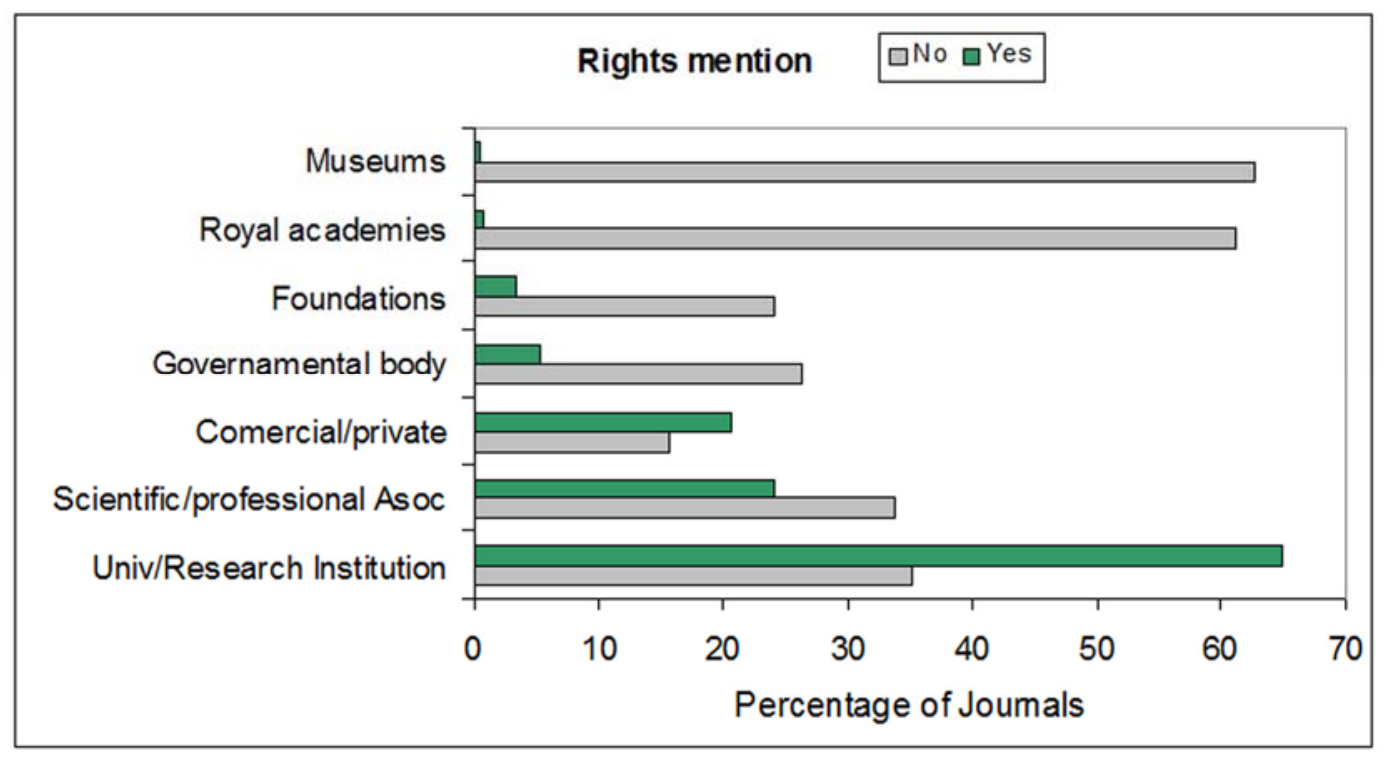

Figure 1 


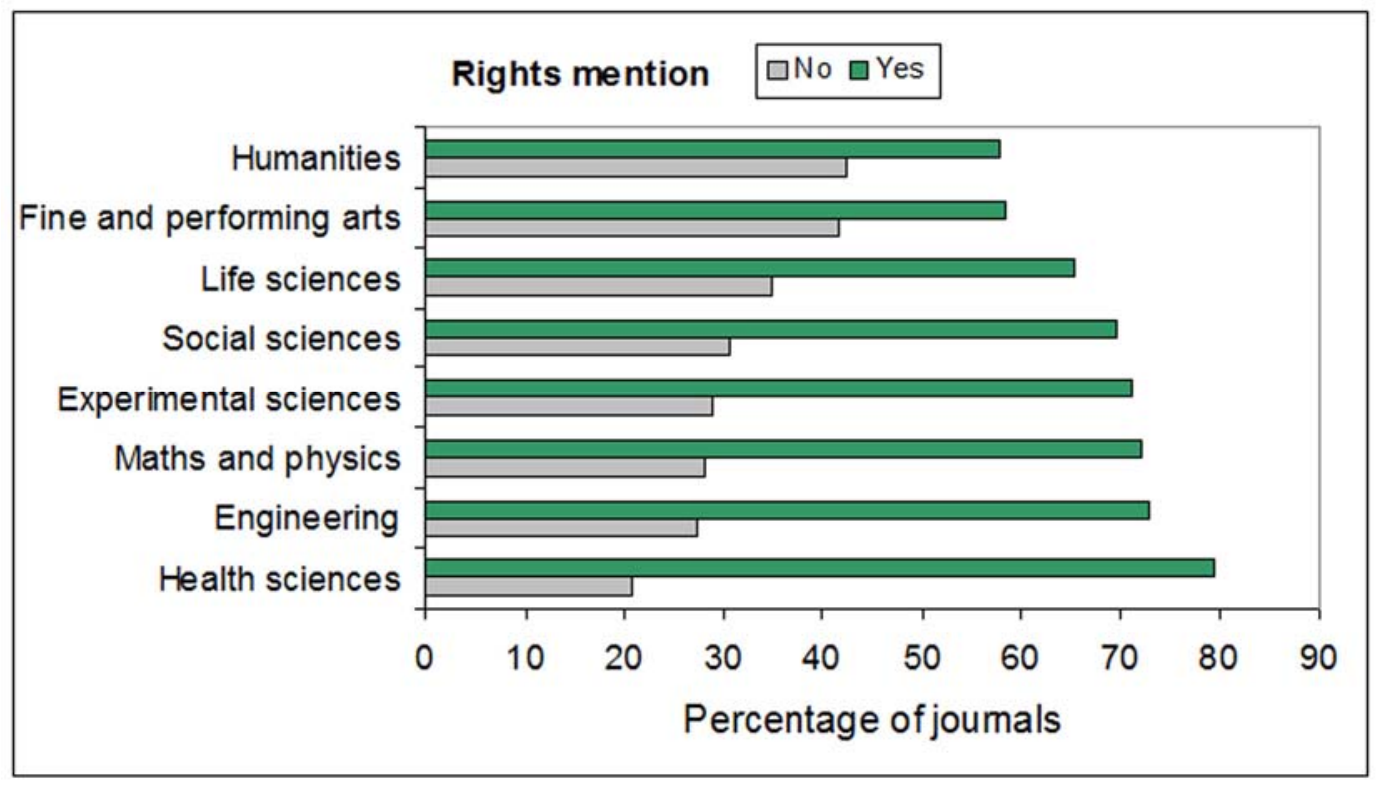

Figure 2 


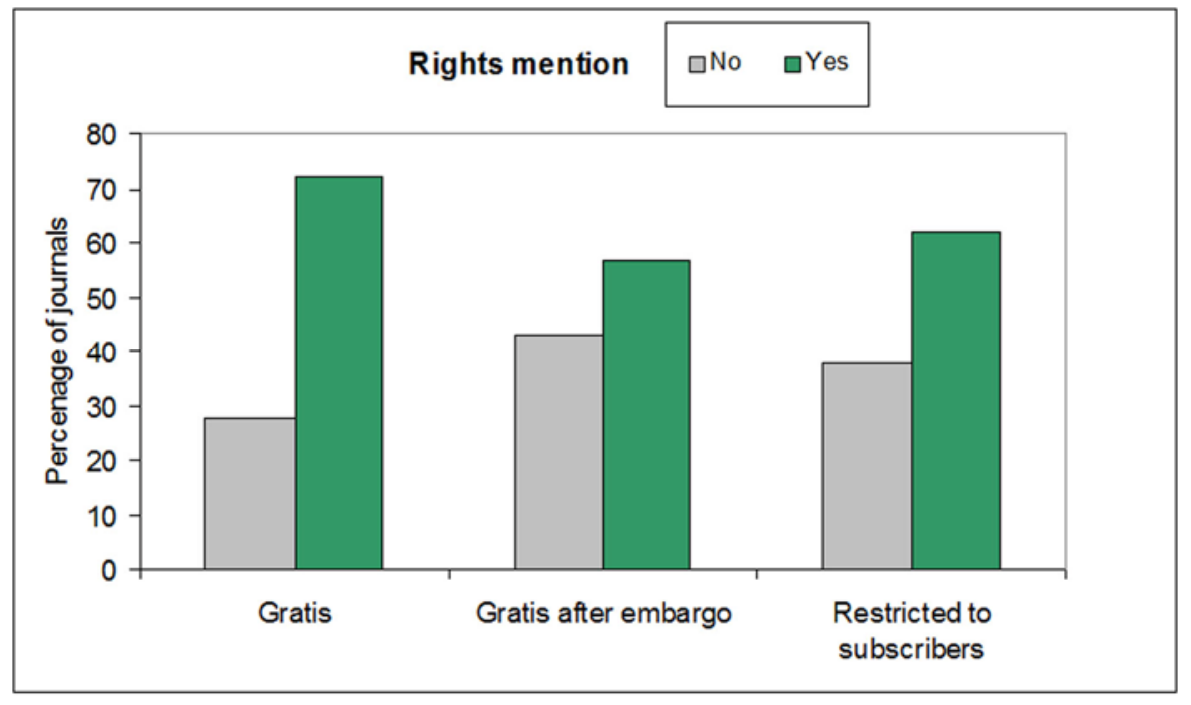

Figure 3 


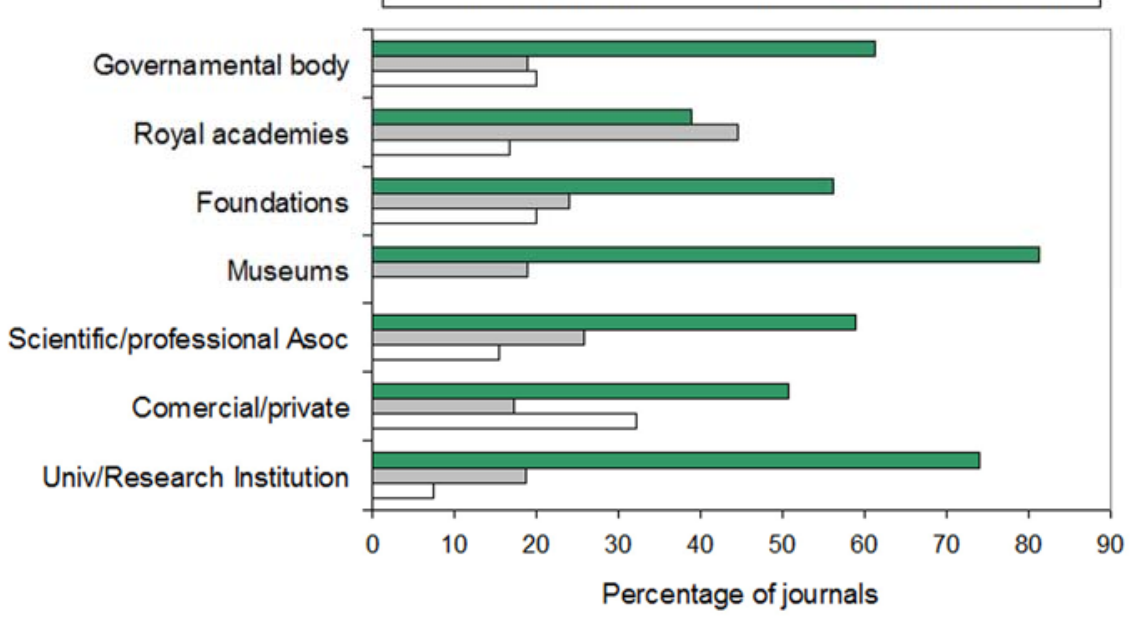

Figure 4 


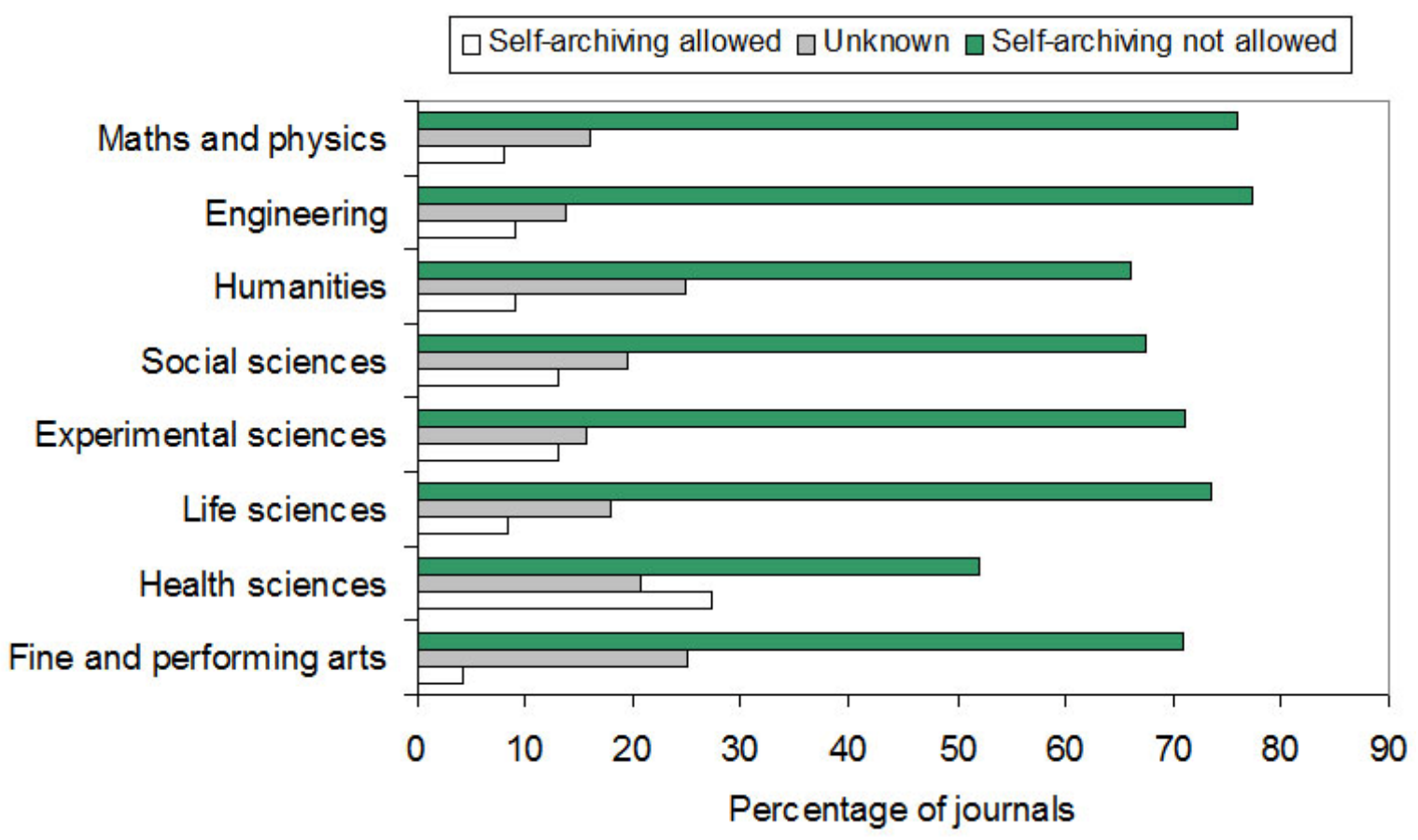

Figure 5 
Joumals by ROMEO colour

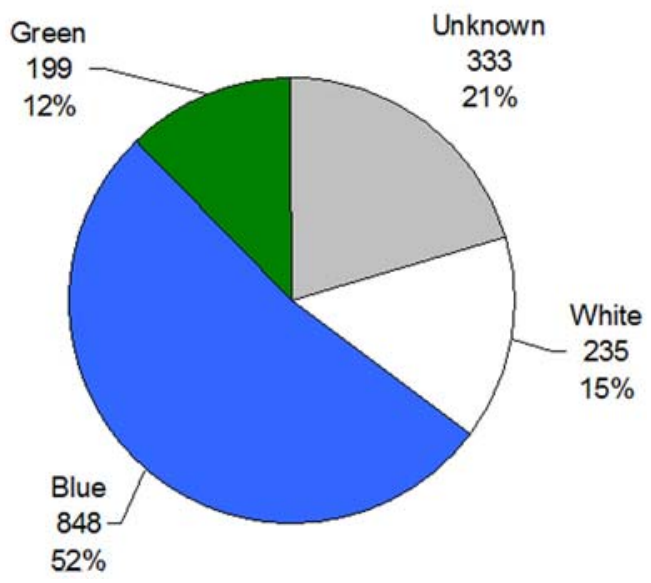

Figure 6 


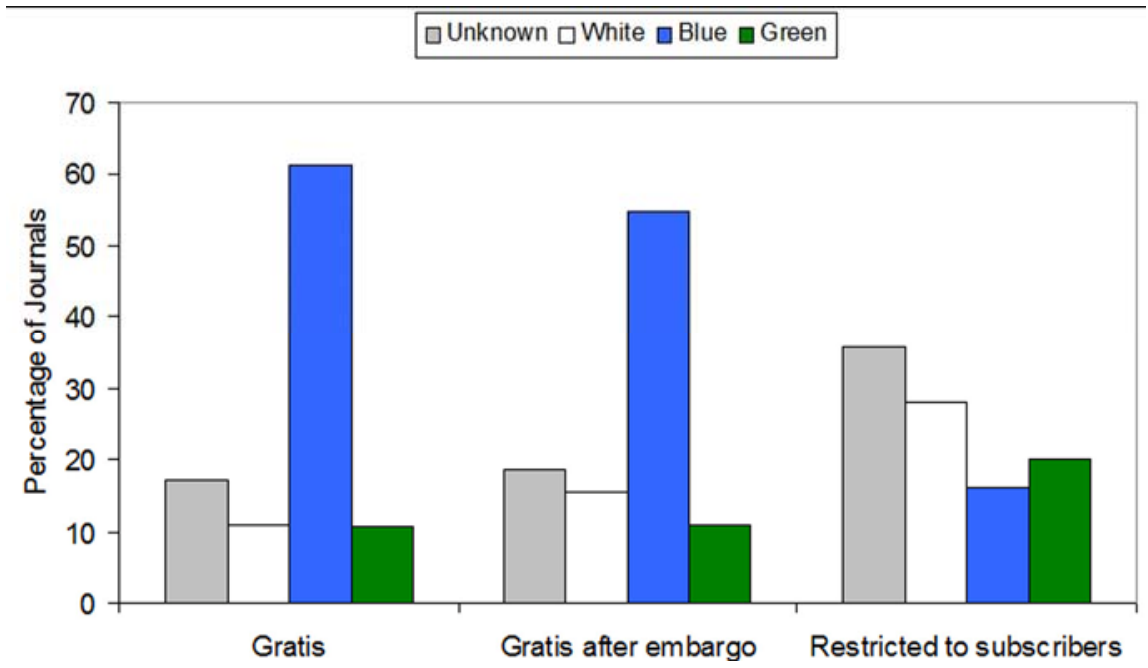

Figure 7 


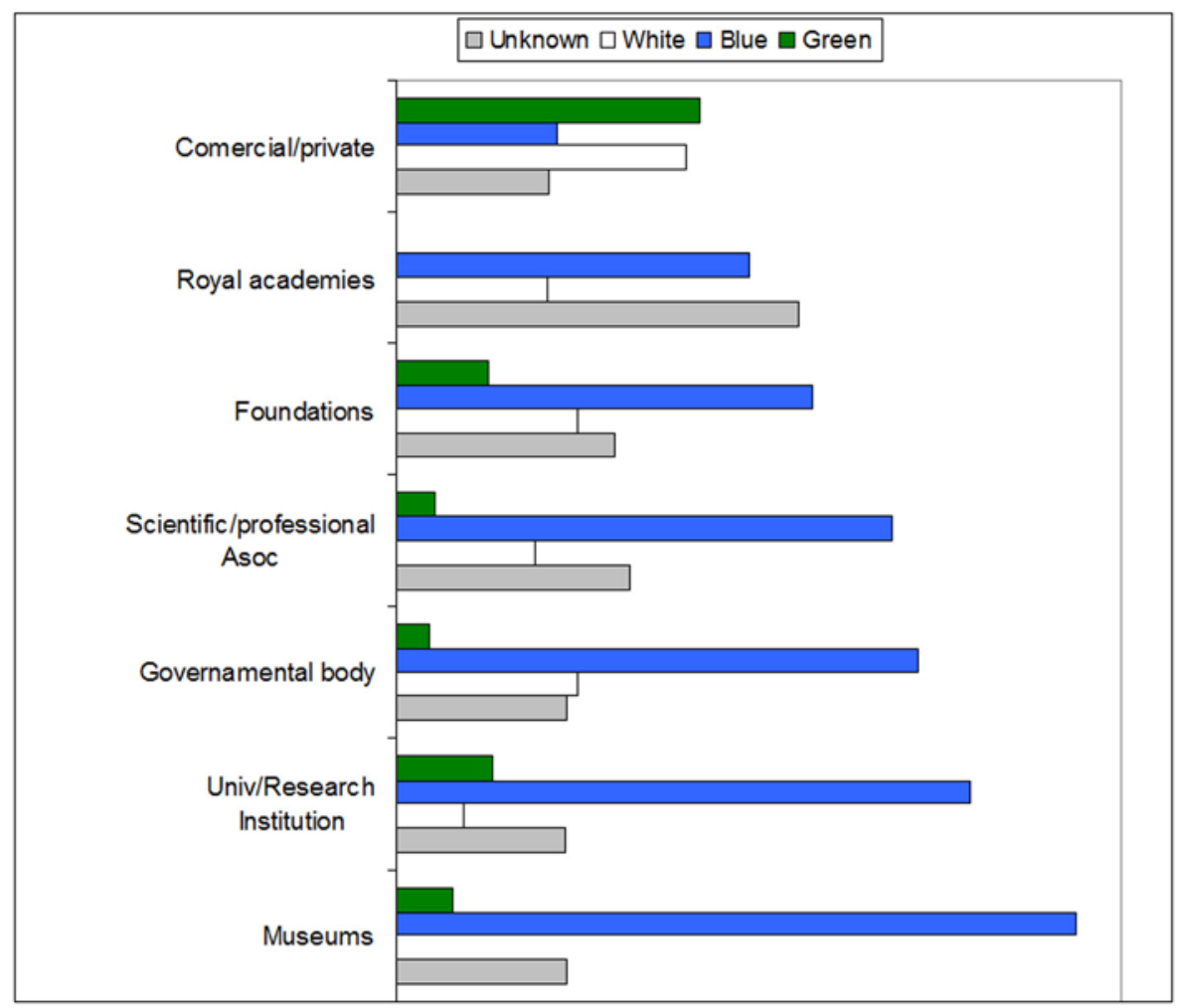

Figure 8 


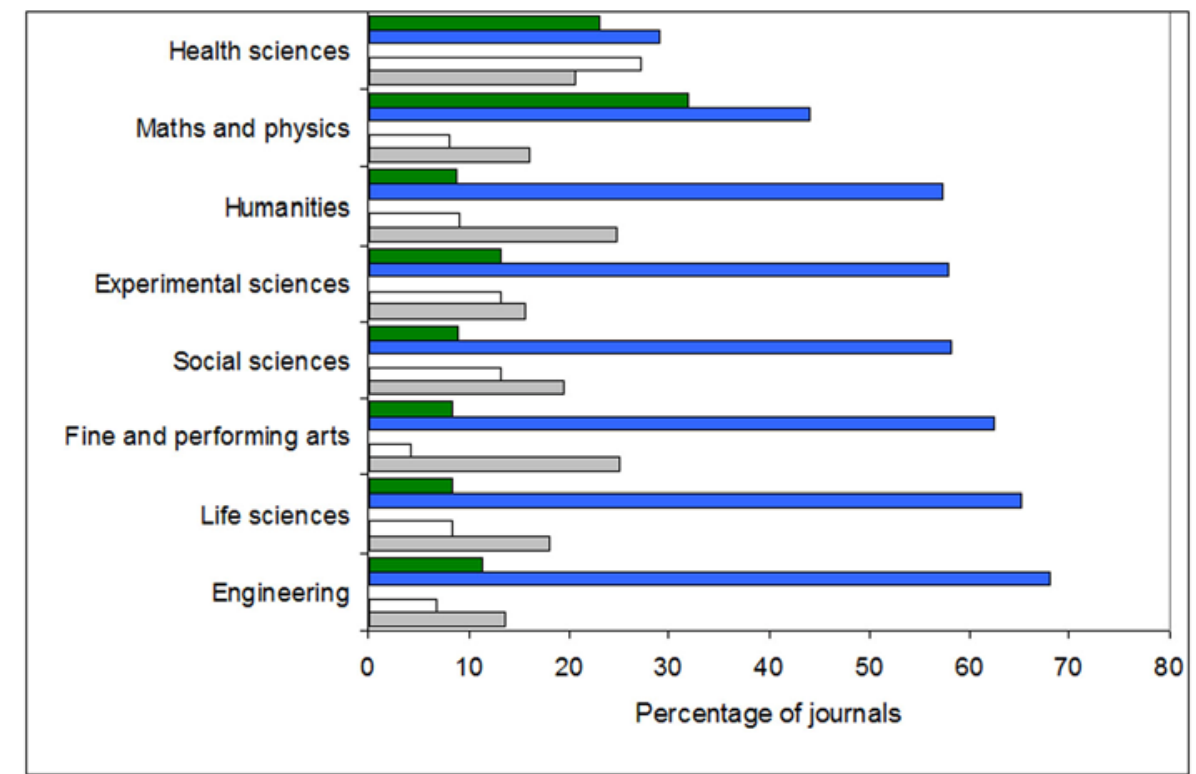

Figure 9 


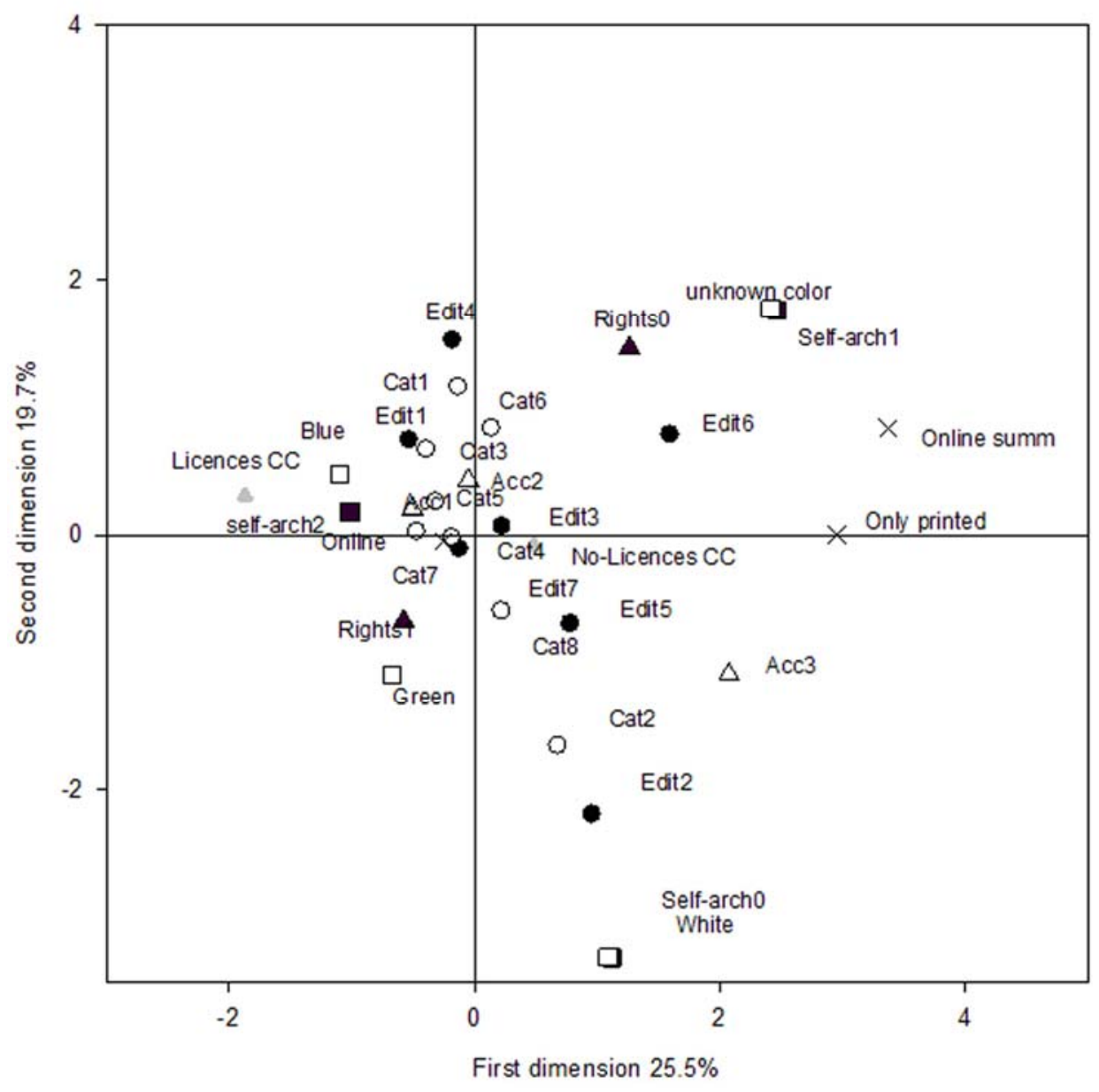

Figure 10 